\title{
Chapter 6 \\ Local Narrative-Making on Refugees: How the Interaction Between Journalists and Policy Networks Shapes the Media Frames
}

\author{
Andrea Pogliano and Irene Ponzo
}

\subsection{Introduction}

Mediatised local events are the gateway for national media narratives, and traditional local media play an essential role of gatekeeping. In this chapter we maintain that local journalism is highly influenced by local news sources, namely the local institutions and all other actors engaged in the issues at stake which are conceptualised here in terms of policy networks (Rhodes 1988; Marsh and Rhodes 1992).

Our previous investigations (Pastore and Ponzo 2016; Pogliano 2016) have suggested that the "narrative autonomy" of local policy networks is greater where they are more cohesive, i.e. when their representations of the issues at stake are consistent and when their actions are coordinated. More cohesive local policy networks appear to be better able to develop their own narratives on migration and self-representations of the local community, and more capable of influencing the media narratives. To a certain degree this study builds upon this hypothesis and further develops this previous work. Specifically, we confronted this approach by elaborating on two particularly significant case studies which are emblematic of the barriers and concentrations

The chapter is the result of research work carried out within the FIERI project "Urban narrativemaking of refugee crises", supported by the Urban Communication Foundation and co-financed by the Compagnia di San Paolo. Part of the content is taken from an article published in the journal Mondi Migranti (Pogliano and Ponzo 2019).

\footnotetext{
A. Pogliano $(\square)$

Università del Piemonte Orientale, Alessandria, Italy

e-mail: andrea.pogliano@uniupo.it

I. Ponzo

FIERI - Forum of International and European Research on Immigration, Turin, Italy

e-mail: ponzo@ fieri.it
}

B. Glorius, J. Doomernik (eds.), Geographies of Asylum in Europe and the Role 
of refugees and migrants who are physically and symbolically reshaping Europe: the Central Station of Milan, where starting in 2013 the number of migrants engaged in trying to reach other European countries multiplied in spite of the rules imposed by the Dublin Convention; and the utilisation in the same year of the abandoned buildings of the MOI area (former Mercati Ortofrutticoli all'Ingrosso, i.e., Fruit and Vegetable Wholesale Market) in Turin by persons granted humanitarian and international protection who, due to restrictions in terms of circulation associated with these statuses, remained trapped in Italy at the end of a reception process that had proven incapable of guaranteeing adequate housing and work integration.

The joint analysis of media and policy dynamics is, in our opinion, the most innovative aspect of this contribution, since the media and policy literature remain substantially separate and unable to dialogue, despite the fact that the strength of the seminal work for media studies, Policing the Crisis, authored by Hall and colleagues in Birmingham 40 years ago, was significantly based on this connection (Hall et al. 1978). ${ }^{1}$

Years after Policing the Crisis, whose idea of the social processes drew from Gramscian concepts of hegemony, hegemonic bloc and strategic alliances, this way of researching communication and society barely survives in studies about moral panics and the media. The legacy of Policing the Crisis has arguably been taken up by social movement studies at least since the work of Touraine (1981), with his conception of society as something produced and reproduced in collective action, and his focus on the issue of who is able to intervene in social processes and how such interventions shape the direction of social process (Eder 2015). However, social movement scholars have often overlooked media and communication processes.

Only in recent years has the study of communication and media processes entered into the research agenda of social movement studies, with several attempts to formalise the role of media and communication (see Teune 2011; Mattoni 2013; Bennett and Segerberg 2015) in the organisation of "contentious collective action" (McAdam et al. 2001). In these studies a key question is about how communication serves social movements in their formation and by raising the visibility of their political claims. To use the words of Bennett and Segerberg (2015), the point is to understand when communication is an expression of existing organisations and when, instead, an organisation is the creation of communication.

Our work is an attempt to move forward by widening the scope of research from social movements to larger policy networks and analysing the logic of the actions and strategies of those networks and the media on an equal footing, avoiding viewing one of the two as instrumental for the other. ${ }^{2}$ In fact, whereas the literature on social

\footnotetext{
${ }^{1}$ In this regard, see the criticism by Curran (2002) of what he calls neoliberal revisionism and its consequences on media research after Policing the Crisis. It should also be noted that, even in the somewhat meagre production of research in the wake of Policing the Crisis, the role of the media is often underrepresented, and when it is central, the themes of migration and asylum are not (see Critcher 2006).

${ }^{2}$ The concept of mediatisation of society and politics (Couldry 2012; Thompson 1995) is a further incentive for reasoning and producing research embedded in a model of society in which collective and political actions operate in constant tension and mutual conditioning with the narratives, categories and logic of the media.
} 
movements is focused mainly on organisations, our analysis is about policy networks which encompass several types of organisations, including social movements, and concerns the pattern of relations between them. Following the distinction proposed by Rhodes (1988) between the national government environment (macro), policy networks (meso) and organisations (micro), we could say that our focus is on the meso rather than on the micro level.

Furthermore, we consider the policy networks and the local media to be mutually involved in the process of narrative-making. Our work concerns the dialectic between policy networks and local media on the issue. How do these dialectical mechanisms produce and reproduce the media frames on migrants and refugees?

This research is based on a mixed qualitative methodology. To study the local policy networks, we analysed the available official documents and carried out 18 semi-structured interviews with local administrations, third sector organisations and social movements.

For the media analysis, we collected news items related to transit refugees in Milan and to the MOI occupation in Turin, by using keywords in the online archives of newspapers. We collected all the news items for the period from the beginning of the media coverage of the two cases - April 2013 for Turin and October 2013 for Milan to the end of June 2016, when the local elections were held in the two cities (in Milan the centre-left coalition kept governing the city while in Turin the centre-left majority led by the Democratic Party was replaced by a Five Star Movement-led majority). The news titles analysed are from the two main national broadsheets with a local newsroom in the cities-La Stampa and Repubblica in Turin, Corriere della Sera and Repubblica in Milan. Specifically, we analysed frequencies and frames of the news items through a qualitative news framing analysis (D'Angelo and Kuypers 2010).

In total, we collected 301 news items for Milan and 162 news items for Turin. Finally, the mechanisms of local journalism in the two cities were investigated through eight semi-structured interviews (four in Milan and four in Turin) with the journalists who ended up being the most involved in covering the stories.

The chapter is structured as follows. Section 6.2 provides a brief overview of the main events in the two cities. Section 6.3 illustrates the local media coverage and framing of the two cases. The results of Sect. 6.3 will be explained through analysis of the organisation and functioning of local journalism (Sect. 6.4) and local policy networks (Sect. 6.5) and their interactions (Sect. 6.6). In the last Sect. 6.7, we will discuss the main findings.

\subsection{Main Events and Turning Points in the Case Studies of Milan and Turin}

\subsubsection{The Transit Refugees in Milan}

According to the Dublin Regulation, refugees have to claim asylum in the first EU country they enter. However, when refugee flows started increasing after the Arab Spring, neither Italy nor Greece identified every refugee and many of them crossed 
borders to reach other European countries. Against this backdrop, Milan was a major passageway to northern Europe since it is close to the border. The phenomenon became significant in 2013 when many Syrian families started spending a few days in the Central Station before resuming travel. Since 2015, sub-Saharan Africans, especially Eritreans, began to arrive as well and after a while they exceeded the number of Syrians who soon moved away from this route. Overall, from October 2013 to April 2016 the number of transit refugees registered by the municipality was 88,067 , peaking at 52,600 in 2014, and finally dropping to 4700 in the first half of 2016.

With the arrival of Syrian refugees, various NGOs (Save the Children, the Eritrean association Cambio Passo, etc.) as well as the City of Milan started offering support at the Central Station, establishing a so-called "hub".

In October 2013, thanks to economic resources provided by the Ministry of the Interior through the local prefecture, accommodation centres run by non-profit organisations (Arca Foundation, Farsi Prossimo, City Angels) were opened. ${ }^{3}$ However, the length of the agreements between the City and the local prefecture was generally a few months. While waiting for the renewal of these agreements, the City repeatedly appealed to non-profit organisations and charities to deliver free accommodation. In fact, some parishes and Catholic NGOs (Casa di Carità, Fratelli di San Francesco, Sant'Egidio), and initially even some mosques, provided beds on a voluntary basis. Support for transit refugees became increasingly structured over time and the activities of screening and relocation to accommodation centres moved several times, eventually settling in April 2016 in the centre in via Sammartini, located along the railway line but further from the station.

Private citizens also rallied to provide help by triggering one of the greatest solidarity mobilisations ever seen in Milan. The summer of 2014 saw the start of what was called the SOS Syria Emergency volunteer group. Initially supported by a few people from the local branch of the Democratic Party, it soon became the largest grassroots volunteer group active at the Central Station. In contrast, right-wing parties and movements staged several anti-refugee demonstrations over the years in question, in both the city centre and the Central Station. However, citizens' participation in those demonstrations was never significant and was largely outnumbered by pro-refugee demos and mobilisations.

The mobilisation of civil society and the institutions has to be framed within the context of the Expo (Universal Exposition) held in Milan in 2015. This had two main relevant consequences. First, the Central Station became a sort of "entryway" into the city, especially from May to October 2015, when the Expo was open to the public. Second, the Expo emphasised the cosmopolitan identity of Milan, which

\footnotetext{
${ }^{3}$ The legal basis for the intervention was the so-called Apulia Law (Law Decree 451/1995 converted into the National Law 563/1995) passed two decades earlier in order to manage flows from the Balkans to southern Italy. The law allows the establishment of emergency centres to accommodate irregular migrants waiting to be identified. Yet, public institutions did not identify refugees staying in Milan's centres, arguing that the Immigration Consolidated Law stipulates that foreigners must submit requests for residence permits to the public authorities within 8 days of their arrival in the country, and none of them stayed that long.
} 
had impacted its approach towards migrant communities since the mid-2000s when preparations for the Expo first started, as immigrant associations and cultural groups were regarded as resources for the city's international outlook (Caponio 2014). This orientation and, more generally, the cosmopolitan atmosphere emphasised by the Expo contributed to limiting xenophobic attitudes among politicians as well as citizens.

The management of the refugee flows, however, was not conflict-free. The clashes were particularly strong between the City, with a centre-left majority, and the Lombardy Region, led by the Northern League, especially when it came to the management of health issues, which in Italy falls under the remit of the Regions. In the autumn of 2014 the Regional Council formally rejected the proposal, repeatedly pushed by the centre-left minority in the region, as well as the City, to set up a fixed medical unit at the Central Station. In order to make up for the lack of health assistance, doctors offered their help on a voluntary basis. Only in June 2015, when several cases of scabies surfaced, did the Lombardy Region finally establish a fixed medical unit at the Central Station to cope with the challenging health situation.

With the closing of borders in 2016, transit became almost impossible. Time spent in the accommodation centres increased and reached an average stay of 100 days in June 2016. Therefore, the large majority of would-be transit refugees ended up requesting asylum in Milan.

\subsubsection{The Occupation of MOI Buildings in Turin}

The occupation that occurred in Turin is intertwined with that of the so-called North Africa Emergency Programme, which started in 2011, triggered by the arrivals following the Arab Spring and the fall of Gaddafi in Libya. The Programme mainly concerned people from central Africa living in Libya who were hosted, upon arrival in Italy, in accommodation centres managed by the Department of Civil Protection and the Ministry of the Interior. When the North Africa Emergency Programme ended, in February 2013, a large majority of the people expelled from the accommodation structures were homeless and unemployed. Between March and April 2013, around 400 of them, most of whom held humanitarian permits, ${ }^{4}$ occupied three buildings of what is known as the MOI (former Mercati Ortofrutticoli all'Ingrosso, i.e., Fruit and Vegetable Wholesale Market) area, located on the eastern edge of the Lingotto neighbourhood, just along the railway line (Fig. 6.1).

The occupied buildings belong to the Olympic Village and are composed of 30 structures that accommodated the athletes during the Winter Games held in Turin in 2006. After the Games, 19 buildings were sold by the City of Turin to the Turin City Fund, a real estate fund whose investors are the City of Turin itself (35\%), Equiter (29\%) and Prelios (36\%). The latter is also the asset management company which

\footnotetext{
${ }^{4}$ The permit of stay for humanitarian reasons lasts 2 years and can be converted into a permit of stay for work. It does not allow holders to freely circulate in Europe.
} 


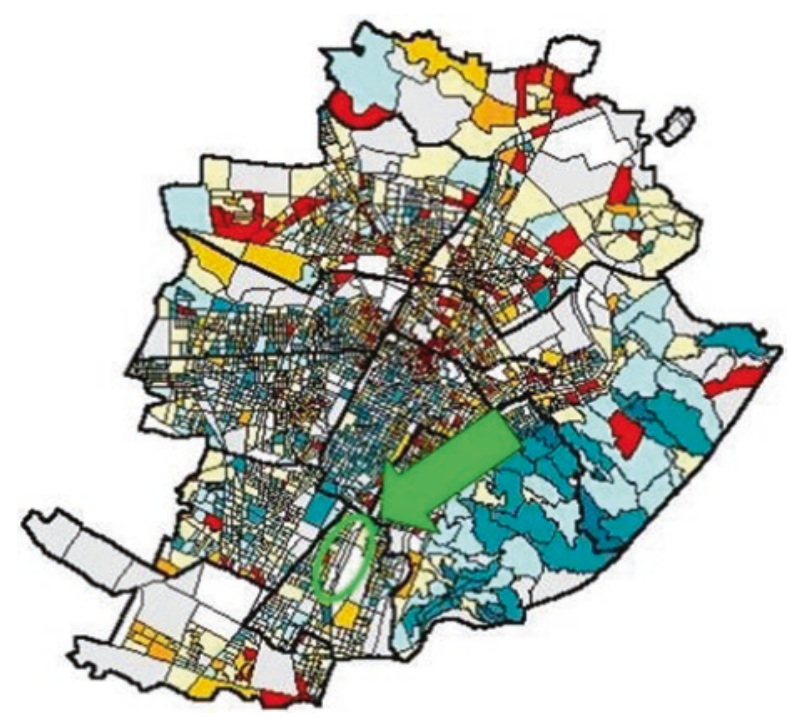

Fig. 6.1 The location of the MOI area in the city of Turin. (Source: Authors' own design)

manages the Fund, is responsible for the reconversion and commercialisation of the buildings and thus acts as owner. Despite the efforts made, four buildings remained unsold and thus empty until the time they were occupied by refugees.

The occupation was supported by the extreme-left organisations Gabrio and Askatasuna, inspired respectively by communist and anarchist ideologies, and by the Migrant and Refugee Movement linked to the radical trade union USB. In the days following the occupation, a Solidarity Committee supported by those organisations was set up with around 15 Italian volunteers and some refugees from the occupation. Neighbourhood residents provided basic goods, no protests were registered, and neither the police nor the Municipality intervened. The occupation soon gained the solidarity of the Archbishop of Turin who visited the occupied buildings in July 2013 and was supported by the Pastoral Office for Migrants (Ufficio Pastorale Migranti, UPM), which is the branch of the diocesane curia responsible for migration issues.

In August 2013, a fourth building, the only empty one left, was autonomously occupied by Somali refugees, the majority of whom came from the previous occupation of Clinica San Paolo which occurred in 2008, and who had never been properly accommodated by the local institutions. Overall, the number of occupants rose to around 600.

During the investigated time period, the main negotiation between the organisations supporting the occupation and the City occurred in the autumn of 2013 and 
concerned the possibility of enrolling the refugees living there on the civil registers in order for them to gain access to local services, sign work contracts and renew their residence permits. ${ }^{5}$ After several public demonstrations and meetings, the City decided to provide homeless refugee ${ }^{6}$ living in the city, including those squatting in the MOI buildings, with an artificial residence ${ }^{7}$ which differs from full residence because it does not allow access to social benefits and, being granted only to homeless people, is regarded as stigmatising. This event marked the breakup of the alliance between the extra-left movements and the Migrant and Refugee Movement since the first were less keen to accept the compromise on artificial residence than the second, and more oriented towards highly participatory approaches and refugees' direct engagement in the negotiation with the City.

Although the public demonstrations played a relevant role, the decision on artificial residence also suited the City's plans. In fact, the City expected the enrolment on civil registers to provide a sort of census of the refugees living in the MOI buildings which should have been the starting point for planning their relocation across the Region through tailored interventions of integration, financially supported by the Ministry of the Interior. In fact, only a portion of people living in the MOI buildings enrolled on the civic registers. The main obstacle to the above relocation plan, however, was the lack of support from the Ministry of the Interior, which did not meet the City's requests to establish national common rules for enrolling homeless refugees on civil registers and to provide economic resources in order to cope with the MOI occupation. This lack of support from the central government was one of the main differences between Turin and Milan and, as we will see in Sect. 6.5, contributed to the opposite outcomes observed in the two cities.

Against this backdrop, the right-wing political opposition in the Municipal Council continuously called for the occupied buildings to be evicted. This request became more pressing in the winter of 2014 when the councillors of the right-wing parties repeatedly tried to enter the occupied buildings to check on the situation inside but were stopped by members of the extreme-left organisations Askatasuna and Gabrio. A municipal councillor from the Northern League claimed to be looking for cocaine and marijuana near the occupied buildings and filmed the scene in order to denounce the drug-selling that he alleged was occurring in the area. In response, the Solidarity Committee organised a 24/7 task force together with the refugees and some neighbourhood residents to oversee the area and push out drug dealers.

\footnotetext{
${ }^{5}$ In fact, resident permit renewal is not dependent on enrollment on the civil register, as specified in a communiqué issued by the Ministry of the Interior on 18 May 2015. However, before that communiqué it seems that the Prefecture of Turin acted differently.

${ }^{6}$ Namely people seeking asylum, granted international protection or holding a residence permit for humanitarian reasons.

${ }^{7}$ The artificial residence is an imaginary address which allows homeless people to enrol on the civil registers, thus obtaining city residency and access to services. Two other artificial addresses already existed at that time, via Casa Comunale 1 and via Casa Comunale 2, for Italian and foreign homeless people, respectively. A new artificial address, via Casa Comunale 3, was created for homeless refugees.
} 
The square in front of the MOI occupation also became the stage for public demonstrations by the Northern League national leader in December 2014 and 2015, and by far right movements. However, as in Milan, citizens' participation was never massive.

Finally, it is worth reporting an episode which gained relevant public attention, namely the alleged rape of a young woman with severe learning disabilities in the occupied buildings in June 2015. The men accused of that crime were caught with the help of the people living in the occupied buildings. ${ }^{8}$ Public demonstrations followed, organised by right-wing parties, and a police garrison began to oversee the area 24/7. At the same time, the Mayor announced a census of the people living in the occupied buildings, though it never happened. In June 2016, the number of people living in the MOI occupied buildings was estimated to be around 1000 .

\subsection{Local Media Coverage and Media Framing}

In this section we report on our analysis of the coverage in the local pages of the examined newspapers and of the frames that informed this journalistic coverage at the narrative level. For the framing analysis we referred to Benson's (2013) distinction between victim frames and threat frames. Through a literature review of both European and the US materials, Benson arrived at a list of 10 broad immigration frames: three victim frames, four threat frames and three hero frames. Victim frames are "the global economy frame", "the humanitarian frame" and "the racism/xenophobia frame". Threat frames are "the jobs frame", "the public order frame", "the fiscal frame", and "the national cohesion frame". 9 The hero frames were irrelevant in our dataset.

\footnotetext{
${ }^{8}$ The final judgement concluded that the young woman spent time with the men, one of whom was her boyfriend, on a voluntary basis but the men were nevertheless sentenced for having taking advantage of a person with severe learning disabilities.

${ }^{9}$ Not all news items express a clear frame. In those cases the news items are irrelevant for the frame analysis. In other cases, more than one frame can be found in the same item: in accordance with most research on media frames, including Benson's, we included in the data set all the frames that appeared in the news items analysed. The more frequent occurrences were clearly those of the humanitarian frame and of the public order frame. The former is defined by Benson thus: "Immigrants are victims of unjust government policies (violations of human rights, fair legal process) or business practices; they suffer from poverty, lack of access to health care, dangers related to border crossing, etc.; or they have difficulties in adapting to their host society". The latter: "Illegal immigrants break the law in coming into this country; once here, immigrants - legal or illegal - are more likely than others to commit crimes, use drugs, and carry diseases; immigrants are coming in such numbers that they threaten overcrowding and environmental degradation". Frames are sometimes directly supported by journalists or they can be found in claim-making from politicians or from members of institutions or civil society, reported in the news. Because our research was conducted on the local sections of national newspapers we considered the page and the position of the articles to be irrelevant.
} 
Fig. 6.2 The coverage of Milan transit refugee news by Repubblica and Corriere della Sera compared with the distribution of city press releases (October 2013June 2016). (Source: Authors' own design)

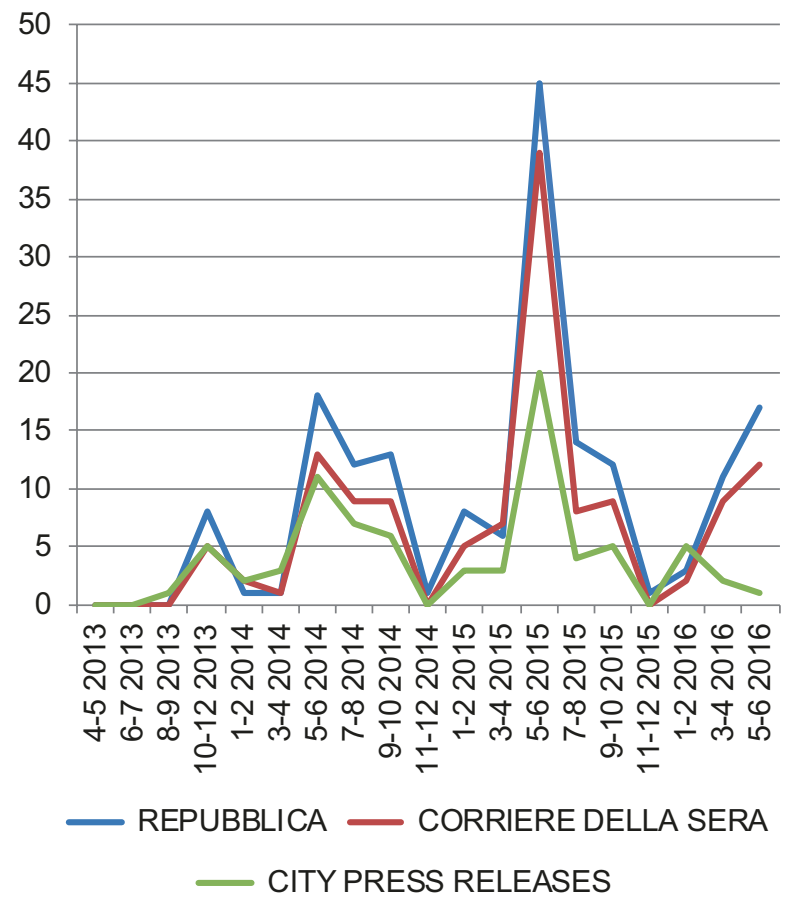

\subsubsection{Milan: Intense Coverage and the Dominance of the Humanitarian Frame}

On transit refugees in Milan, Repubblica produced 171 articles in the 32.5 months from the middle of October 2013 to June 2016, which means an average of 5.26 article per month, while Corriere della Sera produced a total of 130 articles (an average of four each month). Considering only the hot seasons (from May to October), when the numbers of refugees arriving in Milan were higher, we get an average of more than one article every 3 days (12 per month in Repubblica, 11 per month in Corriere) (Fig. 6.2). These numbers of news items allow us to speak of intense coverage.

As indicated, in spite of slightly different absolute numbers, the trend in the coverage over time for the two titles is virtually identical. This is so rare in the analysis of the contents of the media over such a long period of time that the most plausible explanation is twofold: firstly, constant news management of the large number of small news events that occurred during the reference period - confirmed by a comparison with the press releases issued by the City of Milan; and secondly close cooperation, of a community type, between journalists of the two newspapers, similar to what happens with embedded journalists in war contexts. 


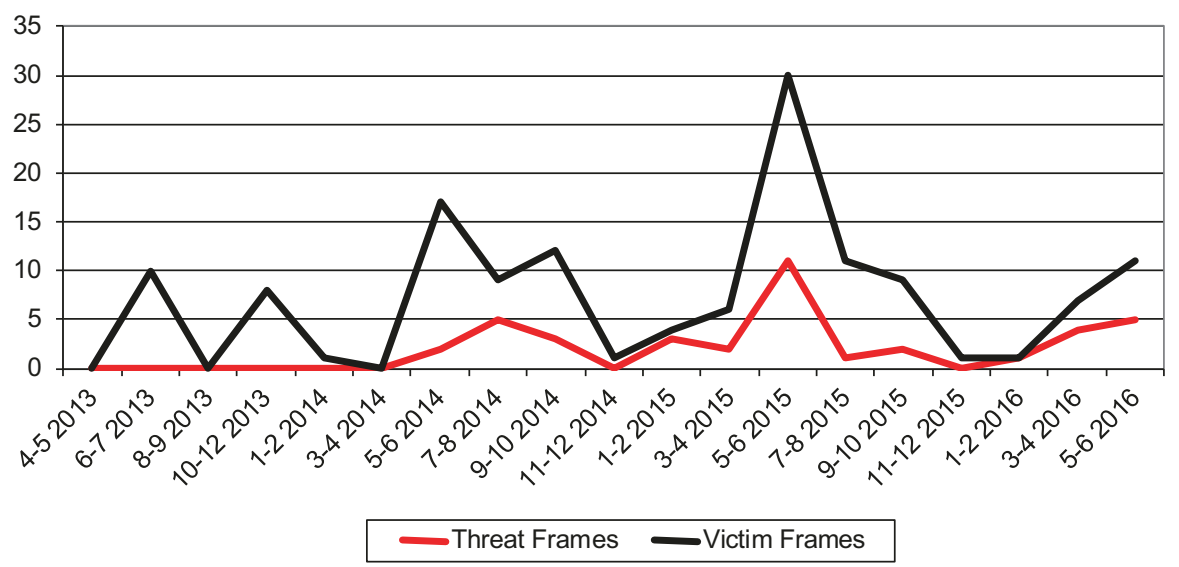

Fig. 6.3 The distribution of frames in Milan transit refugee news (Repubblica + Corriere). (Source: own design)

In general terms, the peaks are easy to explain because of the intensification of refugees crossing the Mediterranean Sea and then transiting to Milan during the hot seasons. The highest peak, that of May-June 2015, which is a media hype (more than a quarter of the entire coverage of 32.5 months is concentrated in this 2-month period), is a consequence of the sum of various factors: (a) the beginning of the hot season with an intensification in the number of refugees, (b) the opening of the Expo in Milan with the resultant increase of attention around the city and its security system, (c) the medical alarm about scabies, (d) right-wing politicians' public statements and demonstrations aimed at creating a public health moral panic, and (e) the local government's communication action efforts in order to counteract the panic.

The victim frames (the humanitarian frame) led the coverage (Fig. 6.3), and even when the threat frames (the public order or the fiscal frame) promoted by right-wing politicians or civic society's protest groups were the real first material for producing news, both newspapers very often embedded the threat frames within news items which started with quotations from the victim frames' supporters. This way of representing the threat frames has been favoured by the strong news management of the Councillor for Social Policies Pierfrancesco Majorino, which aimed to present the local administration as a pragmatic and anti-ideological actor engaged in a sort of resistance against adverse fate ("the State and the Region have left us alone"), and to demonstrate how the local administration was driven by both humanitarian and public order concerns. This kind of constant and coherent communicative action led to a rejection of the racist/xenophobia frame (the accusation of racism in coping with the threat frames) in favour of a distinction between "people who do things" and "people who only talk", where the latter were easily labelled as contradictory and demagogic. 


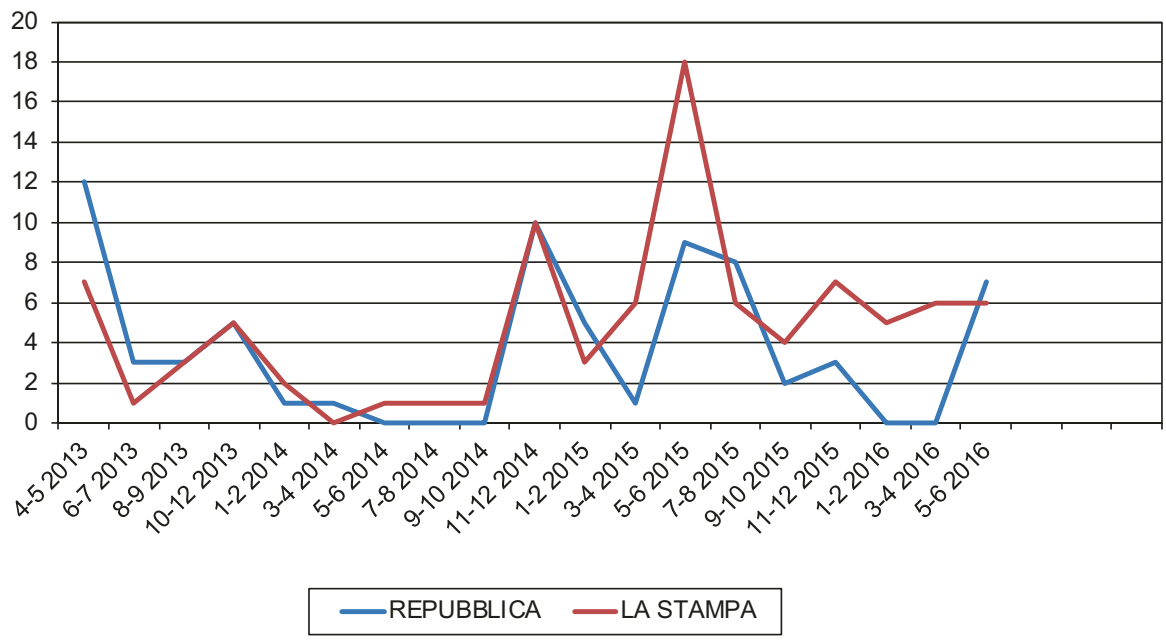

Fig. 6.4 Coverage of the ex-MOI occupation in Turin in the local pages of Repubblica and La Stampa (April 2013 - June 2016). (Source: Authors' own design)

Journalists appear to find that this narrative adheres to the climate of citizen solidarity observed every day in the Central Station by reporters. It is perhaps above all this non-contradiction between narratives that created a "natural" climate for the affirmation of the humanitarian frame in Repubblica and Corriere, which also have few differences in this aspect.

\subsubsection{Turin: Light Coverage and the Dominance of the Public Order Frame}

The coverage of an event such as the MOI occupation would be expected to produce high numbers of articles from local journalism, for various reasons, including the important news value of "quantity" (the number of people involved in the occupation). However, Repubblica produced only 70 articles on it in the 38 months from April 2013 to June 2016, which means an average of 1.84 articles every month, while La Stampa produced a bit more with 92 articles in total (2.4 per month).

The first peak occurs in the beginning of the occupation, the second is registered more than a year later, in November-December 2014, and a third peak occurs in the summer of 2015. These are small peaks, around 10 articles in 2 months, which can be regarded as coverage intensification rather than as media hype. The highest peak is that of La Stampa's coverage of May-June 2015 with 18 articles in 61 days (Fig. 6.4). 


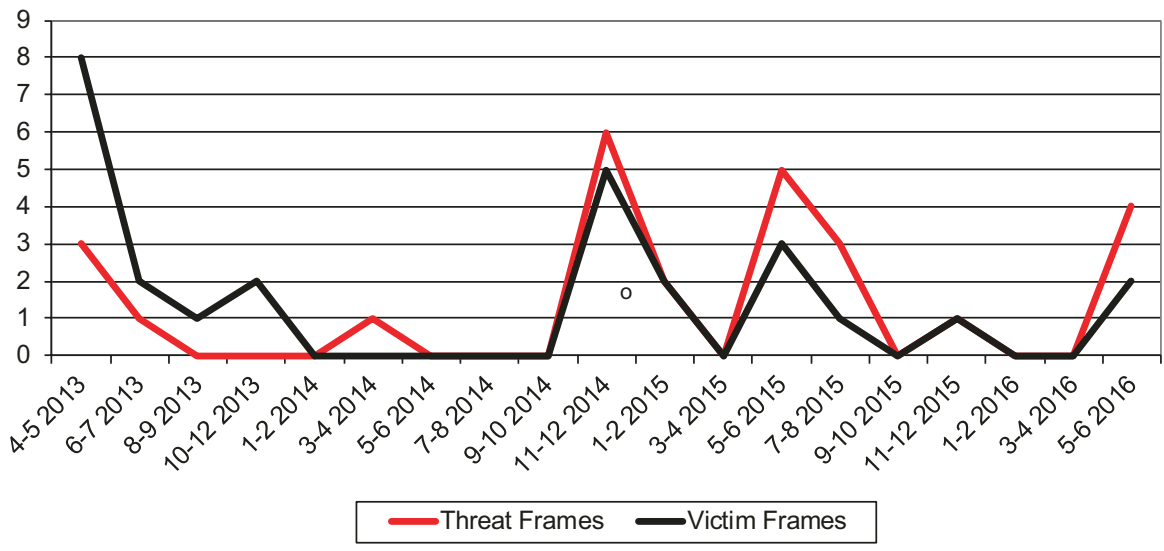

Fig. 6.5 Trend of the victim and threat frames in all the collected articles (Repubblica $+\mathrm{La}$ Stampa) for the case of the ex-MOI occupation in Turin (April 2013 - June 2016). (Source: Authors' own design)

Both the second- and the third-most significant attention spans are due to crime and to statements and protests arising out of these events (drug dealing in the first case, alleged sexual violence in the latter).

Frame analysis (Fig. 6.5) shows a situation in which the victim frames are prevalent in the very first phase of coverage of the occupation, while the threat frames are generally more frequent in the following months. In particular, with respect to the two attention peaks indicated, the public order frame guides the coverage. A detailed analysis of the production of frames in the articles of the two publications reveals a sort of overturning of the narrative structure that dominated the representation in the Milanese case. While in Milan threat frames were evoked in order to contrast the humanitarian frame that structured the story, in the case of the occupation of the MOI - except for the very first phase - the victim frames (in particular the humanitarian frame and the racism/xenophobia frame) encouraged a story built mainly around the frame of public order. The most frequent narration followed this script: it starts with interviews with members of the neighbourhood committees or local and national politicians from right-wing parties who use the public order frame, continues by talking to supporters of the victim frame, and then closes by placing an emphasis on the public order frame.

An aspect of great interest for this work is the following: the victim frames only rarely appear on the pages through the words of political subjects, whether or not they are members of the local administration in charge. The voices that support these frames are those of the Prefecture, the police headquarters and civil society. 


\subsection{The Organisation and Functioning of Local Journalism}

In this section we use interviews with local journalists in Milan and Turin from the above mentioned national newspapers to offer a first explanation of how events were told, which circumstances led to certain narrative productions and the development of frames that prevailed in the journalistic stories of the two cases, as well as relationships with some members of the local policy networks. Three topics are investigated: (a) the professional experience of journalists with respect to migration (6.4.1), (b) the editorial offices of local journalism; and (c) an analysis of the setting, or the work dynamics linked to physical places (6.4.2).

\subsubsection{How Journalists' Specialisation Impacts Local Narratives}

In Italy, despite migration being a central theme for political and media communication, among journalists in the newsrooms of the main daily newspapers, few have specific skills on the topic. This is especially true for local journalists. The trend is made worse by the fact that in Italy local journalism on migration largely relies on the desk production of news based on official sources rather than on first-hand materials, and civic society is often under-represented.

Despite this general framework, some exceptions are present, especially for Milan and Rome. In fact, entities such as Redattore Sociale, Radio Popolare and Avvenire in recent years have formed a group of editors who interpret their work as mostly concerned with the production of a form of news (Barnhurst and Nerone 2001) that Benson (2013) has described as "dramatic personalized narratives" which is closely linked with the humanitarian frame, having its origins in advocacyoriented and social journalism (Schudson 1978).

Some of these journalists were hired by the local editorial offices of national newspapers, especially, if not almost exclusively, in Milan and Rome. In the case of migrants in transit in Milan, this meant the presence of a small group of reporters who are used to dealing with different communities of migrants in their work and are able to frame the local events in a broader context. This situation is quite rare in the city sections of national newspapers that we have analysed, and in the local journalism more broadly. The Turin case exemplifies what turns out to be the norm. Despite the length of the occupation and its direct connection to an important story (the North Africa Emergency and its political management), the journalists engaged in the local narrative were not able to deal with the problem by connecting it in a relevant way to migration issues and to policies concerning migrants and refugees. One of the main reasons is due to the lack of specific skills on the issues being discussed. Local journalists moved from one local event to another, but did not focus on a central theme. When they were engaged in telling the MOI story they were out of their comfort zone. 


\subsubsection{Newsroom Framing and the Reporting Setting}

In part as a consequence of what has been written above, and in part as a result of the choices of the respective newspaper editors, the two cases were in fact framed in the newsrooms we have studied in distinct terms. In Milan, the city sections of the national newspapers analysed favoured an intensive approach, involving a few journalists with specific skills on the issue of migration and asking them to go deep into the story and follow it over time, while in the case of Turin the story was not entrusted to any one journalist, but combined the distinction of privileged tasks and contacts with typical sources of ordinary and routine work. These profound differences led in the Milanese case to the production over time of a clear and coherent editorial frame, while in the Turin case the definition of the situation first shifted from the migratory question to the occupation of buildings and from there took more subtle directions depending on the specific skills of reporters (e.g. the relationship between antagonistic groups and the city administration, neighbourhood dynamics, etc.).

All this was amplified by the extreme diversity of the settings. The Turin case was characterised by the difficulty of journalistic access to the stories of the occupants. In fact, the journalists interviewed complained about the difficulty of entering the MOI, the long waiting times for the decisions of the Solidarity Committee, which were badly adapted to the timetables of the daily news, and a series of prejudices and misunderstandings that sometimes made for strained relations.

The extreme-left movements supporting the occupation failed in their attempt to build strong networks with supportive journalists. Adopting Rucht's (2004) "Four A's" model of social movement media strategy, we noticed that "abstention" was predominant, while "adaptation" was explicitly refused - partly as an opposing reaction to the way journalists reported from the MOI and partly because of the absence of communication staff - while "attack" and "alternative" were limited in their scope, directed to a small radical audience through a couple of "alternative media" forums (Downing 2000). However, instead of the well-documented tendency of the media to report negatively on movements (Gamson 2004), what we noticed in this case had more to do with journalists' lack of trust in the Solidarity Committee as both a source of information and a gateway for accessing the refugees' stories, the latter being related to the fact that the Solidarity Committee was clearly intended to be an intermediary.

With respect to the question of exchanges between journalists, these were lacking because of the absence of a common place in which the reporters of various newspapers could work, or because of the declared absence of meetings inside the editorial offices to discuss the issue of the MOI.

The Milanese situation appears to be the complete opposite. The presence of a public access setting with relatively small dimensions like the Central Station produced a sense of community among the journalists involved, which on some occasions also became a solidarity commitment linked to emergency management. The mix between the role of reporter and that of an active and supportive citizen finds journal- 
istic form in the appeals to collect food and clothing for migrants in transit published on an online platform by journalists of Repubblica reporting from the Central Station, thus building an echo chamber between the City and organised citizens.

\subsection{The Local Policy Networks}

In this section, we will analyse the local policy networks, paying special attention to those elements which can explain the differences in local media narratives highlighted in Sect. 6.3.

Policy networks may indeed differ along several dimensions such as the frequency and continuity of participants' interaction, the variety of interests they express, the distribution of resources and the possibility of finding solutions with advantages for all members through positive-sum games, and the degree of consensus on basic values and paradigms or, at least, on issue definition (Heclo 1978; Marsh and Rhodes 1992). As we will see, the differences between the policy networks of Turin and Milan in many of these dimensions contributed to explaining the diverse outcomes observed in the two cities.

\subsubsection{A Highly Compact and Centralised Policy Network in Milan}

Although the processes of spontaneous mobilisation and the activation of volunteering were extremely important in the Milanese case, the network as a whole soon assumed a compact and strongly centralised configuration revolving around the figure of the Councillor for Social Policies Pierfrancesco Majorino, supported by the Mayor Giuliano Pisapia and the Councillor for Security Marco Granelli, which allowed the network to take quick and fairly coordinated action. In addition to managing the relations among other local institutions and the central government, Majorino maintained direct contact with the media and with the various entities involved in the policy network, organising periodic meetings and frequently visiting the hub.

Beyond the strong coordination role played by Councillor Majorino, a factor that strongly contributed to the compactness of the Milanese policy network was the identification of a clear and circumscribed policy issue, which allowed the field of action of the network policy to be clearly delineated: it was to manage migrants in transit, who were staying in Milan for a few days, with the aim of giving them temporary material support and managing public order and decorum in the station and, more generally, in the city. The issue that in the same time period ignited the European debate - the violation of the Dublin Regulations-seems to have never been a subject of discussion within the local policy network because it was seen as a matter for the central government. 
A second element is represented by the economic resources made available by the Ministry of the Interior, since without them night-time reception would probably have been impossible and the phenomenon of migrants in transit would have turned into a political and social emergency that was difficult to manage.

Finally, the policy network was able to develop thanks to the convergence of interests between the various organisations due to, firstly, the availability of economic resources that acted as an incentive, especially towards the organisations involved in the management of night centres to which these resources were destined and, secondly, by the limited expertise on migratory themes of the people who made up the policy network. ${ }^{10}$ Only Farsi Prossimo (in favour of a more in-depth screening of individual situations and the introduction of legal and psychological support), and Save the Children (particularly attentive to the needs of minors, pregnant women and families) had specific skills on migratory issues when the policy network was established, and they had different approaches from those of the administration, leading to a progressive modification of the intervention over time. The limited number of organisations with complex and specific "visions" on the issue of migrants in transit, together with a "definition of the problem" with clear and rather narrow borders, reduced the internal conflicts of the network, favouring its durability. The main conflict line was between the third sector organisations and spontaneous volunteer service, of which the main and most visible exponent was SOS Syria Emergency, but it focused more on the practical management of certain issues than on the definition of the problem and the solutions for dealing with it. The only major conflict was with the Lombardy Region (Sect. 6.2). However, since the Region is a higher-level body than the City, this rift ended up making the citizen's network policy more compact.

\subsubsection{A Fragmented and Conflictual Policy Network in Turin}

The situation in Turin was completely opposite to the one in Milan. The definition of the policy problem appeared to be extremely complex. In the first place, it concerned people destined to remain in the area, raising, next to issues of public order and the protection of occupants, all the multiple and complex problems that generally concern integration and, specifically, access to work and housing.

Moreover, the organisations belonging to the policy network saw immigration and access to housing as central themes of their mission, with respect to which they affirmed their reference values and defended their own interests, thus ending up reducing the room for negotiation and creating the conditions for strong antagonism between the parties. The Refugee and Migrant Movement, along with the UBS trade union, showed a more pragmatic approach and appeared to be keener to compro-

\footnotetext{
${ }^{10}$ The involvement of organisations with little expertise on migration and asylum was possible because of the "bed and soup" approach of the Municipality aimed at providing light support to transit refugees who spent just a few days in Milan.
} 
mise with the local institutions. In contrast, for the extreme-left movements the ideological aspects had a decidedly greater weight: defence of the rights of the occupants of the MOI is part of a framework of more general protest of the institutions and is linked to a wider struggle for the right to housing, where resistance to evictions and illegal occupations are central instruments. For their part, the diocesane curia and the Pastoral Office for Migrants, far from seeking a clash with the institutions, framed support for the occupiers of the MOI within their mission of solidarity with the most vulnerable. Finally, the municipal administration, intervening in favour of refugees, feared inciting competition for scarce resources, such as housing and work, with citizens who they are required to protect and represent. Moreover, it wanted to avoid dialogue with the extreme-left movements, which used illegal occupations among their main tools in the housing fight, fearing legitimising this strategy of contra legem action at the city level. Overall, since central members of the local network saw the issues at stake as crucial to their core mission, and they held a certain degree of expertise and rather specific perspectives on those issues, room for negotiating shared solutions was lacking.

Relations between local actors were then further complicated by tensions that developed in other policy networks. Relations inside a policy network always occur within a broader context and set of relationships. Therefore we have to consider multiple and overlapping memberships and recognise that action in one network may affect a group's role in other networks (Marsh and Rhodes 1992). The extremeleft movements had for years been in dispute with the administrations led by the Democratic Party on the construction of the TAV (Treno Alta Velocità, i.e., High Speed Train) line. At the same time, the Pastoral Office for Migrants and, even more so, the other third-sector entities of the city that had mobilised during previous occupations of refugees such as that of the San Paolo Clinic had evaluated attempts to collaborate with the municipality as disappointing (Manocchi 2012). They ended up not mobilising for the MOI, or else developed an attitude of great distrust towards the local institutions, at least with respect to their methods of managing occupations. The tensions and mutual distrust generated in other networks reverberated in the specific policy network that developed around the occupation of the MOI.

To these dynamics are added two other important factors that distinguish the Turin case from the Milanese one. The first is the internal division of the local administration, well summarised by the words of an interviewee: within the Council "each of them tried to pass the hot issue onto someone else's shoulders". Whereas in Milan the local administration showed itself to be compact and ready to make support for migrants in transit its standard, in Turin internal conflict and the lack of a shared position probably prohibited the establishment of city platforms involving other local actors and working groups aimed at coordinating and acting jointly.

The second factor is traceable to the lack of financial support from the Ministry of the Interior, which only arrived into the coffers of the local administration after Five Star's victory in the administrative elections in the summer of 2016. In fact, the only relevant agreement among the members of the policy network, which concerned civil registration, occurred in the early stages of the occupation and, from the perspective of the administration, served as an initial census in preparation for an evic- 
tion and relocation intervention that should have happened with the financial support of the Ministry. Given the paralysis of the central government, the City ended up taking a step back and opportunities for joint action within the policy network became thin on the ground.

We can therefore conclude that in Turin the fragmentation of the policy network depended on several factors: the difficulties in defining the problem and therefore the field of action; lack of economic resources; the strong divergence of visions and interests between the organisations belonging to the network and sometimes on the same side, e.g. between organisations supporting the occupation (Refugee and Migrant Movement versus the extreme-left movements), and within the local administration. In Milan we observed completely opposite conditions, which favoured the development of a cohesive network: a definition of the problem that delimited a precise and rather circumscribed field of action; the availability of huge funding from central government and the consequent presence of economic incentives; the convergence of the positions of the components of the policy network as a result of a lack of "strong visions" on migration issues.

\subsection{Interactions Between the Local Policy Networks and the Media}

The different compactness of the two local networks seems to have had significant effects on the quantity and quality of the media narratives through two mechanisms: the management of relations with the media and the degree of consistency of the narratives developed by the components of the policy networks.

In Milan, the Municipality and especially the Councillor for Social Policies Majorino developed close relations with the local media, almost on a daily basis, and completely centralised the communication flows within the policy network. Members of the issue networks generally did not give interviews without passing through his press office, so Majorino was the central "speaker" for the local issue network. Furthermore, some newspapers, such as Repubblica, were close to the local administration and explicitly supported it both generally and in that specific circumstance by amplifying Majorino's messages or calls for citizens to help provide first-aid supplies. These elements appeared to contribute to the development of a sort of "co-production" of public narratives by the policy network and the local media. ${ }^{11}$

With regard to opposition politicians, journalists in Milan all remarked on the low frequency of their communications, explaining it as a reflection of the administration's (successful) news-management operation, but also as a consequence of a vision stimulated by the Expo of migrants as part of the cosmopolitan

\footnotetext{
${ }^{11}$ Jasanoff (2004) used the term co-production to describe the joint generation of knowledge by science and politics.
} 
appearance of the city (Caponio 2014), a climate of opinion particularly sensitive to the fate of the Syrians and a lack of politicisation of the theme, addressed with a pragmatic approach.

If direct and frequent contact with Councillor Majorino was the true strength of coverage with regard to hard news, the search for stories also passed through the associations present in Central Station, mostly stable and "close at hand" for all the reporters. However, those sources did not produce alternative narratives: the compactness of the Milanese policy network and the sharing of a certain "definition of the problem" and of the solutions to be pursued by its members produced the convergence of the narratives given to the media.

In contrast, the communication strategy of the City of Turin was explicitly aimed at limiting outward communication and relations with local media according to a strategy that we can define as "non-communication". As a result, journalists all complained of a lack of information despite attempts to contact the policy representatives. In this vacuum of political communication on the occupation, the police headquarters and especially the Prefecture were the main institutional sources. Although it contributed largely to supporting the humanitarian frame from the first day of the occupation, acting as a "primary definer" (Hall et al. 1978), it must be said that the communication strategy of these institutions seemed to journalists like a "firefighter" who runs around extinguishing some fires, while keeping the remaining fires at a minimum level of visibility, communicating as little as possible, even on the news stories that had reached the limelight. This dynamic can be explained by the fact that in Turin the institutions, i.e. local administration, police headquarters and Prefecture, did not have shared solutions to communicate and indeed were careful to avoid statements that could exacerbate conflicts within an already very weak and divided policy network. At the same time, as we have said, journalists' access to the MOI occupation was anything but easy, so it was also difficult to collect the voices of the organisations that supported the occupation and the refugees themselves. In this situation, journalists looking for information on the occupation increasingly gave more space to protest committees and demonstrations of political opposition, however limited and unrepresentative they were, opening the door to narratives which were often distant from and contradictory to those of local authorities.

\subsection{Conclusions}

The literature on the relations between media and political actors - mainly dealing with social movements and agenda-setting - is often unable to account for the complex local mechanisms leading to the production of media frames. By combining the two sets of literature on policy networks and on the media, we have tried to identify new hypotheses. 
The local institutions are crucial sources of information for the mainstream local media (Ekström et al. 2012) — what Hall et al. (1978) called primary definers. When they achieve the leadership of a network and keep control over frame production through the creation of a coherent and shared narrative, as happened in Milan, media production follows and it is unlikely that the political opposition will see its frames efficiently represented. However, when local institutions fail either to act as the primary definer or support the development of a cohesive policy network and shared narratives, things risk falling apart. Under such conditions, the media tend both to follow the traditional news values of conflict and sensationalism (Altheide and Snow 1979) and to look for information from any available voice, with the risk of overweighting and overexposing protest groups and opposition parties, as occurred in Turin. We can thus affirm our hypothesis that the cohesion of the local policy networks, understood as shared frameworks and operational cooperation, strengthens their "narrative autonomy", namely their ability to produce public narratives and impact those of the media.

Alongside the cohesion of the local policy networks, on which our initial hypothesis was focused, the presence of a cohesive local media community, i.e., a group of journalists sharing the same definition of the situation and exchanging information and contacts, has emerged as key in developing positive and coherent media narratives. More generally, the conditions of journalists' work in itself, not only in terms of news-making routines (Maneri and ter Wal 2005), but also in terms of knowledge and orientations, are crucial in shaping reporting on refugees and migrants. In this regard our findings highlight the central role played by another factor, namely expertise (or lack of expertise) on migration and asylum, which can be defined as having reported experiences from the migrant or refugee perspectives (so-called advocacy journalism), and commitment to "the cause". Where such expertise and commitment are greater, the local media community tends to be more cohesive and the media frames more positive.

Paradoxically, while expertise and commitment have an adhesive function for the local media community, they might play a disruptive role within the policy community since they tend to generate different and not negotiable definitions of the situation and desired solutions.

To conclude, we can affirm that the main factor able to explain the different evolution of the media narratives in the two analysed case studies is the cohesion of the local policy and media communities. That cohesion seems to be in turn influenced by different elements such as the actors' expertise and commitment, and the role played by local institutions which are a sort of primi inter pares and hold a stronger position compared to the other actors. Nevertheless, we cannot exclude that other members of the policy networks could be key in producing cohesive communities and promoting consistent narratives, even if this has not emerged from our analysis. In order to assess the possibility of generalising our empirical results and explore different configurations, further research is needed. 


\section{References}

Altheide, D. L., \& Snow, P. S. (1979). Media logic. Thousand Oaks: Sage.

Barnhurst, K. G., \& Nerone, J. (2001). The form of news. A history. New York: The Guildford Press.

Bennett, W. L., \& Segerberg, A. (2015). Communication in movements. In D. Della Porta \& M. Diani (Eds.), The Oxford handbook of social movements (pp. 367-382). Oxford: Oxford University Press.

Benson, R. (2013). Shaping immigration news. A French-American comparison. Cambridge: Cambridge University Press.

Caponio, T. (2014). Integration policies for immigrants of the City of Milan, Italy. KING In-depth Study n.10/October 2014. http://king.ismu.org/wp-content/uploads/Caponio_InDepthStudy10. pdf. Accessed 2 May 2019.

Couldry, N. (2012). Media, society, world. Social theory and digital media practices. Cambridge: Polity Press.

Critcher, C. (2006). Moral panics and the media. Maidenhead: Open University Press.

Curran, J. (2002). Media and power. New York: Routledge.

D’Angelo, P., \& Kuypers, J. A. (Eds.). (2010). Doing news framing analysis. Empirical and theoretical perspectives. New York: Routledge.

Downing, J. D. H. (2000). Radical media. Rebellious communication and social movements. London: Sage.

Eder, K. (2015). Social movements in social theory. In D. Della Porta \& M. Diani (Eds.), The Oxford handbook of social movements (pp. 31-49). Oxford: Oxford University Press.

Ekström, M., Johansson, B., \& Larsson, L. (2012). Journalism and local politics. In S. Allan (Ed.), The Routledge companion to news and journalism (pp. 256-266). London: Routledge.

Gamson, W. A. (2004). Bystanders, public opinion, and the media. In D. A. Snow, S. A. Soule, \& H. Kriesi (Eds.), The Blackwell companion to social movements (pp. 242-261). Malden: Blackwell.

Hall, S., Critcher, C., Jefferson, T., Clarke, J., \& Roberts, B. (1978). Policing the crisis: Mugging, the state and law and order. London: Macmillan.

Heclo, H. (1978). Issue networks and the executive establishment. In A. King (Ed.), The new American political system (pp. 87-107). Washington, DC: AEI.

Jasanoff, S. (2004). States of knowledge: The co-production of science and social order. New York: Routledge.

Maneri, M., \& ter Wal, J. (2005). The criminalisation of ethnic groups: An issue for media analysis. Forum: Qualitative Social Research, 6(3). http://www.qualitativeresearch.net.

Manocchi, M. (2012). Richiedenti asilo e rifugiati politici. Percorsi di ricostruzione identitaria: il caso torinese. Milan: Franco Angeli.

Marsh, D., \& Rhodes, R. A. W. (Eds.). (1992). Policy networks in British government. Oxford: Oxford University Press.

Mattoni, A. (2013). Repertoires of communication in social movement processes. In B. Cammaerts, A. Mattoni, \& P. McCurdy (Eds.), Mediation and protest movements (pp. 39-56). Bristol/ Chicago: Intellect.

McAdam, D., Tarrow, S., \& Tilly, C. (2001). Dynamics of contention. New York: Cambridge University Press.

Pastore, F., \& Ponzo, I. (2016). Boundaries, barriers and bridges: Comparative findings from European neighbourhoods. In F. Pastore \& I. Ponzo (Eds.), Changing neighbourhoods: Intergroup relations and migrant integration in European cities (pp. 177-200). Dordrecht: Springer. (IMISCOE). 
Pogliano, A. (2016). News media and immigration in the EU: Where and how the local dimension matters. In F. Pastore \& I. Ponzo (Eds.), Changing neighbourhoods: Inter-group relations and migrant integration in European cities (pp. 151-176). Dordrecht: Springer. (IMISCOE).

Pogliano, A., \& Ponzo, I. (2019). Asilo e crisi urbane: dinamiche di narrative-making tra media e policy network locali. Mondi Migranti, 1, 119-141.

Rhodes, R. A. W. (1988). Beyond Westminster and Whitehall. London: Unwin-Hyman.

Rucht, D. (2004). The quadruple "A". Media strategies of protest movements since the 1960s. In W. Van de Donk, B. D. Loader, P. G. Nixon, \& D. Rucht (Eds.), Cyberprotest: New media, citizens and social movements (pp. 29-56). London: Routledge.

Schudson, M. (1978). Discovering the news. A social history of American newspapers. New York: Basic Books.

Teune, S. (2011). Communicating dissent: Diversity of expression in the protest against the G8 summit in Heiligendamm. In H. Kouki \& E. Romanos (Eds.), Protest beyond borders: Contentious politics in Europe since 1945 (pp. 86-102). Oxford: Berghahn Books.

Thompson, J. B. (1995). The media and modernity. A social theory of the media. Stanford: Stanford University Press.

Touraine, A. (1981). The voice and the eye. Cambridge: Cambridge University Press.

Open Access This chapter is licensed under the terms of the Creative Commons Attribution 4.0 International License (http://creativecommons.org/licenses/by/4.0/), which permits use, sharing, adaptation, distribution and reproduction in any medium or format, as long as you give appropriate credit to the original author(s) and the source, provide a link to the Creative Commons license and indicate if changes were made.

The images or other third party material in this chapter are included in the chapter's Creative Commons license, unless indicated otherwise in a credit line to the material. If material is not included in the chapter's Creative Commons license and your intended use is not permitted by statutory regulation or exceeds the permitted use, you will need to obtain permission directly from the copyright holder.

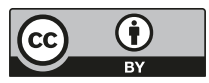

